Article

\title{
Improved Growth and Yield Response of Jew's Mallow (Corchorus olitorius L.) Plants through Biofertilization under Semi-Arid Climate Conditions in Egypt
}

\author{
Ahmed Fathy Yousef ${ }^{1,2,+}$, Mohamed Ahmed Youssef ${ }^{3,+}$, Muhammad Moaaz Ali ${ }^{1}$ (D), \\ Muhammed Mustapha Ibrahim 1,4 (D), Yong Xu ${ }^{5,6, *}$ and Rosario Paolo Mauro ${ }^{\text {,*(D) }}$ \\ 1 College of Horticulture, Fujian Agriculture and Forestry University, Fuzhou 350002, China; \\ ahmedfathy201161@yahoo.com (A.F.Y.); muhammadmoaazali@yahoo.com (M.M.A.); \\ scholarmusty@yahoo.com (M.M.I.) \\ 2 Department of Horticulture, College of Agriculture, University of Al-Azhar (branch Assiut), \\ Assiut 71524, Egypt \\ 3 Department of Soils and Water, College of Agriculture, University of Al-Azhar (branch Assiut), Assiut 71524, \\ Egypt; Dr_mayoussef@azhar.edu.eg \\ 4 Department of Soil Science, University of Agriculture Makurdi, Makurdi 972211, Nigeria \\ 5 College of Mechanical and Electronic Engineering, Fujian Agriculture and Forestry University, \\ Fuzhou 350002, China \\ 6 Institute of Machine Learning and Intelligent Science, Fujian University of Technology, 33 Xuefu South Road, \\ Fuzhou 350118, China \\ 7 Dipartimento di Agricoltura, Alimentazione e Ambiente (Di3A) Via Valdisavoia, \\ Università degli Studi di Catania, 5-95123 Catania, Italy \\ * Correspondence: y.xu@fafu.edu.cn (Y.X.); rosario.mauro@unict.it (R.P.M.); Tel.: +86-591-8378-9374 (Y.X.); \\ +39-095-4783314 (R.P.M.) \\ + Both authors contributed equally to this work.
}

Received: 17 October 2020; Accepted: 13 November 2020; Published: 16 November 2020

\begin{abstract}
This study was conducted to comparatively assess the effects of fertilization typology (organic, inorganic, and biofertilization) on the growth, yield, and compositional profile of Jew's mallow. The experiment was carried out over two growing seasons, under semi-arid climate conditions on silty loam soil. We adopted three fertilization strategies: (1) inorganic NPK fertilizer (146, 74, and $57 \mathrm{~kg} \mathrm{ha}^{-1}$ for $\mathrm{N}, \mathrm{P}_{2} \mathrm{O}_{5}$, and $\mathrm{K}_{2} \mathrm{O}$, respectively), (2) farmyard manure $\left(36 \mathrm{~m}^{3} \mathrm{ha}^{-1}\right)$, and (3) a biofertilizer (a set of mixed cultures of Bacillus spp., Candida spp., and Trichoderma spp. at $36 \mathrm{~L} \mathrm{ha}^{-1}$ ). Treatment combinations were control (without fertilization, $\mathrm{T}_{1}$ ), NPK fertilizer $\left(\mathrm{T}_{2}\right)$, farmyard manure (FYM, $\left.T_{3}\right)$, biofertilizer $\left(T_{4}\right)$, NPK+biofertilizer $\left(T_{5}\right)$, and FYM+biofertilizer $\left(T_{6}\right)$. The $\mathrm{T}_{5}$ treatment maximized both plant and leaf biomass (up to 31.6 and $8.0 \mathrm{t} \mathrm{ha}^{-1}$, respectively), plant height $(68.5 \mathrm{~cm})$, leaf area $\left(370 \mathrm{~cm} \mathrm{~m}^{-2}\right)$, leaf protein content $(18.7 \%)$, as well as $\mathrm{N}, \mathrm{P}$, and $\mathrm{K}$ concentration in leaves $\left(2.99,0.88\right.$, and $2.01 \mathrm{mg} 100 \mathrm{~g}^{-1}$, respectively). The leaves' weight incidence was lower in $\mathrm{T}_{5}$ treatment $(36.7 \%)$ as compared to the unfertilized plants $\left(\mathrm{T}_{1}\right)$. The results revealed that the combined application of inorganic NPK plus biofertilizer is most beneficial to increase growth, yield, and nutrient accumulation in Jew's mallow plants.
\end{abstract}

Keywords: leafy vegetable; mineral nutrients; soil structure; chlorophyll content; cation exchange capacity 


\section{Introduction}

Over the years, mineral fertilizers have helped agriculture enhance crop productivity to meet the ever-increasing demand for food. However, the overutilization of inorganic fertilizers poses a negative impact on the environment and soil functioning and fertility [1]. Moreover, it leads to the high cost of crop production. Therefore, many researchers have tried to restore soil fertility through the use of organic materials of plant or/and animal origin, in the forms of organic fertilizers. Organic fertilization involves the use of naturally occurring material that includes animal manures and agricultural residues [2]. These materials have been proposed to boost the supply of inorganic nutrients, which can bridge fertilizer demand due to economic and environmental reasons [3]. Organic manure increases the status of soil nutrients via the gradual release of minerals to the soil as well as enhancing its physical, biological, and chemical properties [4,5]. Also, organic manure has been shown to improve the agronomic performances of many crops [6].

Biofertilizers are substances containing living organisms and organic materials that can be utilized to increase soil nutrients availability and promote plant growth and productivity. They are also considered an eco-friendly way toward sustainable agriculture because they do not cause pollution $[7,8]$. Biofertilizers have become a preferable alternative or supplement to organic and inorganic fertilizers. Therefore, to increase soil productivity, the utilization of biofertilizers has become increasingly important, because they help in stimulating plant growth hormones, thereby enhancing nutrients uptake and increasing tolerance towards several abiotic stressors too [9]. Biofertilizers can be applied to seeds, soils, rhizosphere, or plant surfaces. Moreover, they are less costly and sometimes more effective as compared to inorganic fertilizers [10-12] Jew's mallow (Corchorus olitorious L.) belongs to the Malvaceae (Tiliacea) family and classed in the genera of about 40-100 species of the flowering plants [13]. It is also known as jute mallow in English and called Mulukhiyah in Egypt. The leaves are edible either fresh, dried, or frozen by many Egyptians because it is a quite cheap vegetable and forms part of the national Egyptian dishes [8]. It is one of the popular tropical green leafy vegetables of great importance in most countries in the Middle East and Latin America [14], Africa, and Asia [15].

Jew's mallow is a source of income for smallholders and poor families in Egypt, farmers cultivate Jew's mallow in many marginal areas. They use their seeds, which consequently result in genetic diversity in Jew's mallow distribution in Egypt [16]. Recently, Jew's mallow, which is a neglected and underutilized crop species (NUS), has received great international recognition because of its role in providing food and nutrition security and income opportunities among smallholder farmers. Moreover, NUS can be utilized to adapt agriculture and food systems to climate change [17]. Jew's mallow plays an important role in humans nutrition because its leaves contain an average $13-15 \%$ dry matter, $4.7 \mathrm{mg}$ vitamin A, 259-266 mg Ca, 250-261 Mg, 4.5-8 mg Fe, 4.8-6 g protein, $92 \mu \mathrm{g}$ foliates, $105 \mathrm{mg}$ ascorbic acid, $1.5 \mathrm{mg}$ nicotinamide, $0.9 \mathrm{~g}$ folic acid, $0.7 \mathrm{~g}$ oil, $5 \mathrm{~g}$ carbohydrate, and $1-5 \mathrm{~g}$ fiber per $100 \mathrm{~g}$ of edible leaves $[13,18]$. Additionally, the seeds of $C$. olitorius can be integrated into livestock feeds and human diets [19].

Jew's mallow performs well in marginal areas, even without the addition of organic and/or inorganic fertilizers, as well as under fertilized conditions, especially with application of $N$ [20]. In this regard, Olaniyi and Ajibola [21] found that the use of N, P, and K fertilization significantly increased plant height, fresh shoots biomass, number of leaves, and dry matter content of Jew's mallow above the control (no fertilization). Thus, it is concluded that the yields and growth of the crop could significantly be improved by soil application of N, P, and K fertilizers at the optimum rate of 45, 30, and $20 \mathrm{~kg} \mathrm{ha}^{-1}$, respectively. Also, Aisha, et al. [22] found that application of $70 \%(100,100$, and $80 \mathrm{~kg} \mathrm{ha}^{-1} \mathrm{NPK}$, respectively) of inorganic fertilizer recommended rate on spinach plants gave rise to the longest harvest period, the highest total weight of leaves and its various organs and improve leaves nutritional values, including $\mathrm{N}, \mathrm{P}, \mathrm{K}$, and protein contents. However, using biofertilizers in Jew's mallow cultivation has not received adequate attention, whether singly or in integrated use with organic and inorganic fertilizers. Similarly, the effects of these combinations on the nutrient uptake require proper understanding and documentation, which is still lacking in the reported literature. 
Therefore, this study aimed to assess the bio-agronomical response of Jew's mallow to the combined soil incorporation of organic, inorganic and biofertilization, so checking the possibility to obtain a more sustainable fertilization technique for the crop.

\section{Materials and Methods}

\subsection{Experimental Site}

A two-year field experiment was carried out under semi-arid climate conditions on silty loam soil at the Research Farm of the College of Agriculture, Al-Azhar University, Assiut branch. The location is $\left(27^{\circ} 12^{\prime} 16.67^{\prime \prime} \mathrm{N} ; 31^{\circ} 09^{\prime} 36.86^{\prime \prime} \mathrm{E}\right)$ in Assiut governorate, Egypt. Table 1 shows some physical and chemical properties of the soil at the experimental site, collected at a depth of $0-30 \mathrm{~cm}$ and analyzed as described by [23].

Table 1. Some physical and chemical properties of the experimental soil in 2017 and 2018.

\begin{tabular}{|c|c|c|c|}
\hline \multirow{2}{*}{\multicolumn{2}{|c|}{ Parameter }} & \multicolumn{2}{|c|}{ Value } \\
\hline & & 2017 & 2018 \\
\hline \multirow{3}{*}{ Particle Size Dist. } & Sand (\%) & 20.0 & 18.3 \\
\hline & Silt (\%) & 56.5 & 59.6 \\
\hline & Clay (\%) & 23.5 & 22.1 \\
\hline \multicolumn{2}{|c|}{ Texture grade } & Silty loam & Silty loam \\
\hline \multicolumn{2}{|c|}{ pH Susp. (1:2.5) } & 8.22 & 8.28 \\
\hline \multicolumn{2}{|c|}{ E.C $\left(\mathrm{dSm}^{-1}\right)$ soil past } & 0.487 & 0.336 \\
\hline \multicolumn{2}{|c|}{ O.M (\%) } & 1.98 & 1.91 \\
\hline \multicolumn{2}{|c|}{ Total $\mathrm{CaCO}_{3} \%$} & 1.48 & 1.42 \\
\hline \multicolumn{4}{|c|}{ Cations (cmol.kg ${ }^{-1}$ soil) } \\
\hline \multicolumn{2}{|c|}{$\mathrm{Ca}^{++}$} & 8.54 & 6.89 \\
\hline \multicolumn{2}{|c|}{$\mathrm{Mg}^{++}$} & 13.56 & 10.43 \\
\hline \multicolumn{2}{|c|}{$\mathrm{Na}^{+}$} & 22.72 & 18.07 \\
\hline \multicolumn{2}{|c|}{$\mathrm{K}^{+}$} & 3.32 & 2.12 \\
\hline \multicolumn{4}{|c|}{ Anions (cmol.kg ${ }^{-1}$ soil) } \\
\hline \multicolumn{2}{|c|}{$\mathrm{HCO}_{3}^{-}$} & 6.54 & 4.87 \\
\hline \multicolumn{2}{|c|}{$\mathrm{Cl}^{-}$} & 20.52 & 16.65 \\
\hline \multicolumn{2}{|c|}{$\mathrm{SO}_{4}=$} & 2.84 & 2.15 \\
\hline
\end{tabular}

$\overline{\text { Each value represents a mean of three replicates. E.C: electrical conductivity; O.M: organic matter. }}$

\subsection{Experimental Design and Treatments}

Treatments were laid out using a randomized blocks design with three replications. Each plot unit included a totally flat area of $10.5 \mathrm{~m}^{2}$. The seeds of Jew's mallow were sprinkled on 25 March 2017 and 2 April 2018 for each season, respectively. The irrigation of experimental units was immersed-way once per 10 days, as per local custom. Weeds were removed manually at 20 and 40 days after sowing (DAS) in both growing seasons, before irrigation was affected. The treatments application comprised three fertilization types (alone or in combinations), namely an organic fertilization (farmyard manure, FYM), an inorganic NPK fertilization, and a biofertilizer. The organic fertilizer was obtained from the animal Production Farm, College of Agriculture, Al-Azhar University, Assiut, and was incorporated into the soil during plowing at the recommended dose of $36 \mathrm{~m}^{3} \mathrm{ha}^{-1}$. Its chemical composition was reported by Silva [24] and presented here in Table 2. For the inorganic fertilization, the recommended $\mathrm{P}_{2} \mathrm{O}_{5}$ dose of $74 \mathrm{~kg} \mathrm{ha}^{-1}$ (as Ca super phosphate) was incorporated into the soil during plowing, while $146 \mathrm{~kg} \mathrm{ha}^{-1}$ (as urea) and $57 \mathrm{~kg} \mathrm{ha}^{-1} \mathrm{~K}_{2} \mathrm{O}$ (as potassium sulfate) were divided in two equal applications at 10 and 20 DAS, as commonly used for growing Jew's mallow plants, recommended by the Ministry of Agriculture [25]. The liquid biofertilizer (T.S) contains of molasse as organic material carrier of microorganisms, and a set of mixed cultures of Bacillus circulans, B. poylmyxa, B. megatherium, 
Candida spp., and Trichoderma spp., whose amount in terms of living cells was $>0.5 \times 10^{9} \mathrm{cfu} \mathrm{ml}^{-1}$, $>2 \times 10^{7} \mathrm{cfu} \mathrm{ml}^{-1},>1.5 \times 10^{9} \mathrm{cfu} \mathrm{ml}^{-1},>1.5 \times 10^{7} \mathrm{cfu} \mathrm{m}^{-1}$ and $>0.5 \times 10^{6} \mathrm{cfu} \mathrm{ml}^{-1}$, respectively. The biofertilizer was added at $36 \mathrm{~L} \mathrm{ha}^{-1}$ with irrigation in three equal doses at 20, 30 and 40 DAS. The biofertilizer was obtained from the directorate of Agriculture in Assiut. Overall, the trials comprised an unfertilized control $\left(\mathrm{T}_{1}\right)$, inorganic NPK fertilization $\left(\mathrm{T}_{2}\right)$, farmyard manure $(\mathrm{FYM})\left(\mathrm{T}_{3}\right)$, biofertilizer $\left(\mathrm{T}_{4}\right)$, inorganic NPK+biofertilizer $\left(\mathrm{T}_{5}\right)$, and FYM+biofertilizer $\left(\mathrm{T}_{6}\right)$.

Table 2. Chemical composition of farmyard manure used in the experiments on dry weight basis.

\begin{tabular}{cccc}
\hline Characteristic & Values & Characteristics & Values \\
\hline Total-N \% & 1.87 & $\mathrm{pH}(1: 5)$ Susp. & 8.43 \\
Total-P \% & 1.12 & $\mathrm{EC}\left(\mathrm{dSm}^{-1}\right)(1: 5)$ & 4.030 \\
Total-K \% & 2.06 & C/N Ratio & $12: 1$ \\
Organic-C \% & 22.91 & Organic matter \% & 40.43 \\
\hline \multicolumn{5}{c}{ EC: Electrical Conductivity. }
\end{tabular}

\subsection{Data Collection}

Data were collected using plant samples from $0.5 \mathrm{~m}^{2}$ in the middle of each experimental unit. Plant height was taken from the base of the rhizome to the top of the plant using a ruler. The fresh biomass of total plants, fresh weight of leaves, and dry weight of leaves was weighed using an electronic balance $(0.01 \mathrm{~g})$. Fresh biomass of total plants and fresh weight of leaves were put in paper bags and transferred to a drying oven at $70{ }^{\circ} \mathrm{C}$ until constant weight to obtain the dry weight. Leaf area was estimated as described by Pandey and Singh [26], whereas leaf weight incidence, expressed on a percentage basis, was calculated by using the following Equation (1).

$$
\text { Leaves dressing }(\%)=\frac{\text { leaves dry weight }(\mathrm{g})}{\text { plant dry weight }(\mathrm{g})} \times 100
$$

Harvesting was done in the two seasons at 28-May and 5-Jun, respectively. The following soil properties were determined after harvest: cation exchange capacity (CEC) and organic-C, determined according to Clark, et al. [27]. The soil bulk density was calculated by using Equation (2).

$$
\text { Soil bulk density }=\frac{\text { Dry wieght of bulk sample }(\mathrm{g})}{\text { the volume of soil core }(\mathrm{cm} 3)}
$$

Leaf samples from each experimental unit during two seasons were collected, the fifth leaf from the top of 20 plants after 65 DAS (the first season) and 62 DAS (second season), and washed three times with distilled water, before chemical analysis. N-content in leaves was determined using the Kjeldahl procedure according to Motsara and Roy [28]. P-content in leaves was determined by the colorimeter method (ammonium molybdate) using a JENWAY 6305 UV/Visible Spectrophotometer at $643 \mathrm{~nm}$ (OD643) [28]. K-content in leaves was determined photometrically using a Flame Photometer (BWB Model BWB-XP, 5 Channel) as described by Motsara and Roy [28]. Protein content in leaves (expressed on a percentage basis) was calculated as $\mathrm{N}$ content (\%) X 6.25. Leaf chlorophyll content was determined using a mobile chlorophyll meter (SPAD-502-m Konica Minolta, Inc., Tokyo, Japan). Before taking the readings, the performance of the chlorophyll meter was calibrated according to the manufacturer' instructions. At the measurement date, 6 readings from each replicate were taken at 65 DAS (the first season) and 62 DAS (second season), using the youngest fully expanded leaves.

\subsection{Statistical Analysis}

All data collected were subjected to one-way analysis of variance (ANOVA) using SPSS statistical software package version 16.0 (SPSS Inc., Chicago, IL, USA). Significantly different means were 
separated using Duncan's multiple range test at the $p \leq 0.05$ level of probability [29]. Mean values were presented as mean $\pm \mathrm{SD}$.

\subsection{Weather Condition during the Experiment}

During the first year of experiment (2017), the average mean temperature was $26.3^{\circ} \mathrm{C}$, with a gradual increase from 3 April $\left(17.3^{\circ} \mathrm{C}\right)$ to 15 May $\left(29.7^{\circ} \mathrm{C}\right)$, whereas average minimum and maximum temperatures fluctuated between $11-28.4^{\circ} \mathrm{C}$ and $24.6-40.8^{\circ} \mathrm{C}$, respectively. The average relative humidity varied between $20 \%$ and $60 \%$, with the lowest value recorded at 20 April and the highest one at 13 April (Figure 1). During the second year of experiment (2018), the average mean temperature was $28.6^{\circ} \mathrm{C}$, with a gradual increase from $20.8^{\circ} \mathrm{C}$ to $31.5^{\circ} \mathrm{C}$, whereas average minimum and maximum temperatures fluctuated between $12-28{ }^{\circ} \mathrm{C}$ and $20.8-46^{\circ} \mathrm{C}$, respectively. The average relative humidity varied between $16 \%$ and $58 \%$, with the lowest value recorded at 6 May and the highest one at 6 April (Figure 1).

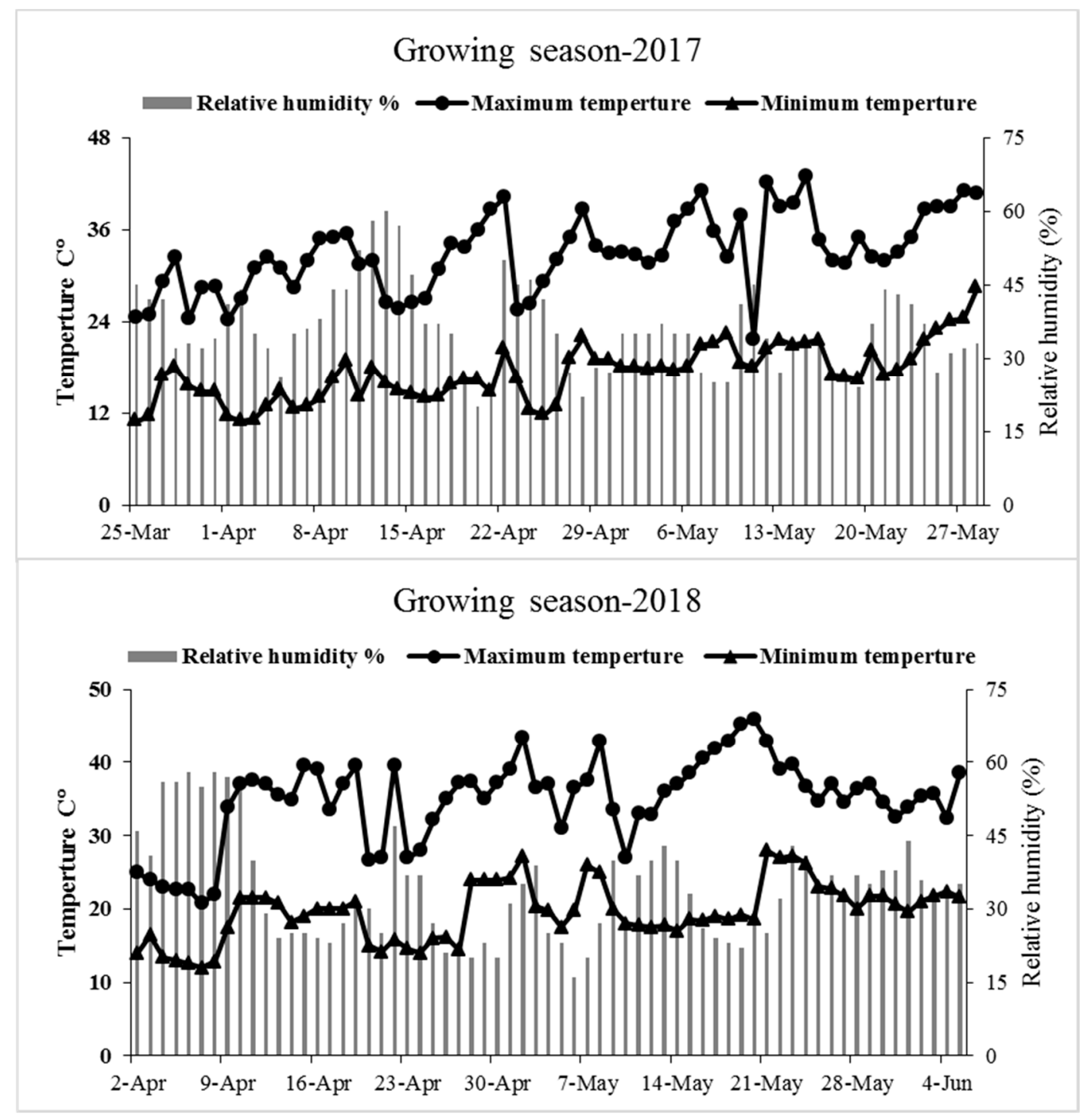

Figure 1. Weather conditions during the two growing periods of Jew's mellow cultivation. 


\section{Results}

\subsection{Growth Variables}

Tables 3-5 show the effect of organic, inorganic, and biofertilizers supplementations on the growth and yield of Jew's mallow plants. The results showed no significant difference in the plants height under $T_{2}, T_{3}, T_{5}$, and $T_{6}$, but they were higher than those under the other treatments in the mean of both growing seasons (Table 3). There were statistically significant differences between the treatments, where the maximum fresh plants weight, leaves fresh weight, plant dry weight, leaves dry weight, and leaves area $\left(3.16 \mathrm{~kg} \cdot \mathrm{m}^{-2}, 797.88 \mathrm{~g} \cdot \mathrm{m}^{-2}, 646.79 \mathrm{~g} \cdot \mathrm{m}^{-2}, 223.35 \mathrm{~g} \cdot \mathrm{m}^{-2}\right.$, and $369.5 \mathrm{~cm}^{2} . \mathrm{m}^{-2}$, respectively) were showed by the plants treated with NPK with biofertilizers $\left(\mathrm{T}_{5}\right)$, and that of without fertilization, $\mathrm{T}_{1}$ treatment gave the lowest values (Tables 3 and 4 ) in the mean of both growing seasons.

The highest leaves weight incidence was observed in plants treated with biofertilizer $\left(\mathrm{T}_{4}\right)$ having non-significant difference among FYM+biofertilizer $\left(\mathrm{T}_{6}\right)$, NPK fertilizer $\left(\mathrm{T}_{2}\right)$, and $\mathrm{T}_{1}$ during first growing season, while in second growing season the plants treated with $\mathrm{T}_{1}$ showed significant highest values (Table 5). There was no significant difference in dry matter content of plants under all the treatments except $\mathrm{T}_{1}$, but $\mathrm{T}_{4}$ was higher than other treatments in the first season, while in the second season, there was no significant difference in dry matter contents of plants in $T_{1}, T_{4}, T_{5}$, and $T_{6}$ treatments, but $\mathrm{T}_{4}$ was highest compared to other treatments in the mean of both growing seasons.

\subsection{Compositional Variables}

As shown in Tables 3-5, the accumulation of protein in Jew's mallow plants in both seasons was the significantly highest under NPK with biofertilizers $\left(\mathrm{T}_{5}\right)$. Data presented in Table 6 shows that the average accumulation of $\mathrm{N}, \mathrm{P}$, and $\mathrm{K}$ in leaves were under $\mathrm{T}_{5}$ higher than other treatments in both growing seasons, while $\mathrm{T}_{1}$ gave the least $\mathrm{N}, \mathrm{P}$, and $\mathrm{K}$ accumulation. 
Table 3. Effect of organic, inorganic, and biofertilizers on plant growth characteristics (plant height, plant fresh weight, and leaves fresh weight) of Jew's mallow (Corchorus olitorius L.) plants.

\begin{tabular}{|c|c|c|c|c|c|c|c|c|c|}
\hline & \multicolumn{2}{|c|}{ Plant Height (cm) } & \multirow{2}{*}{ Means } & \multicolumn{2}{|c|}{ Plant Fresh Weight $\left(\mathrm{kg} \mathrm{m}^{-2}\right)$} & \multirow{2}{*}{ Means } & \multicolumn{2}{|c|}{ Leaves Fresh Weight $\left(\mathrm{g} \mathrm{m}^{-2}\right)$} & \multirow{2}{*}{ Means } \\
\hline & 2017 & 2018 & & 2017 & 2018 & & 2017 & 2018 & \\
\hline $\mathrm{T}_{1}$ & $34.33 \pm 2.31^{c}$ & $25.67 \pm 3.51^{b}$ & $30.00^{c}$ & $1.33 \pm 0.10^{\mathrm{e}}$ & $1.02 \pm 0.06^{c}$ & $1.18^{\mathrm{e}}$ & $478.81 \pm 29.25^{\mathrm{c}}$ & $348.22 \pm 11.57^{\mathrm{c}}$ & $413.52^{\mathrm{e}}$ \\
\hline $\mathrm{T}_{2}$ & $78.33 \pm 2.60^{a}$ & $50.67 \pm 9.45^{\mathrm{a}}$ & $64.50^{\mathrm{a}}$ & $2.13 \pm 0.04^{c}$ & $1.86 \pm 0.15^{c}$ & $2.00^{c}$ & $655.71 \pm 78.74^{\mathrm{b}}$ & $503.07 \pm 12.03^{c}$ & $579.39^{c}$ \\
\hline $\mathrm{T}_{3}$ & $75.67 \pm 4.51^{\mathrm{a}}$ & $49.67 \pm 5.69^{a}$ & $62.67^{a}$ & $2.52 \pm 0.09^{b}$ & $2.26 \pm 0.11^{b}$ & $2.39^{b}$ & $748.79 \pm 58.24^{b}$ & $592.33 \pm 15.25^{b}$ & $670.56^{\mathrm{b}}$ \\
\hline $\mathrm{T}_{4}$ & $51.33 \pm 4.04^{b}$ & $45.33 \pm 2.52^{a}$ & $48.33^{\mathrm{b}}$ & $1.64 \pm 0.22^{d}$ & $1.25 \pm 0.14^{\mathrm{d}}$ & $1.45^{\mathrm{d}}$ & $543.38 \pm 54.65^{c}$ & $433.03 \pm 15.47^{\mathrm{d}}$ & $488.21^{\mathrm{c}}$ \\
\hline $\mathrm{T}_{5}$ & $84.33 \pm 4.16^{\mathrm{a}}$ & $52.67 \pm 3.51^{\mathrm{a}}$ & $68.50^{a}$ & $3.57 \pm 0.05^{\mathrm{a}}$ & $2.74 \pm 0.14^{\mathrm{a}}$ & $3.16^{\mathrm{a}}$ & $897.79 \pm 17.21^{\mathrm{a}}$ & $697.97 \pm 14.64^{\mathrm{a}}$ & $797.88^{\circ}$ \\
\hline $\mathrm{T}_{6}$ & $82.33 \pm 8.33^{a}$ & $51.67 \pm 2.08^{\mathrm{a}}$ & $67.00^{\mathrm{a}}$ & $1.71 \pm 0.16^{\mathrm{d}}$ & $1.41 \pm 0.02 \mathrm{~d}$ & $1.56^{\mathrm{d}}$ & $549.79 \pm 55.22^{c}$ & $427.75 \pm 4.6^{\mathrm{d}}$ & $488.77^{\mathrm{c}}$ \\
\hline Means & $67.72^{\mathrm{a}}$ & $45.95^{\mathrm{b}}$ & & $2.15^{\mathrm{a}}$ & $1.76^{\mathrm{b}}$ & & $645.71^{\mathrm{a}}$ & $500.40^{\mathrm{b}}$ & \\
\hline
\end{tabular}

Values are means of three replicates; different letters in the same column indicate significant differences according to Duncan's multiple range test at $p \leq 0.05$. Where without fertilization

$\left(T_{1}\right)$, NPK fertilizer $\left(T_{2}\right)$, farmyard manure $\left(T_{3}\right)$, biofertilizer $\left(T_{4}\right)$, NPK+biofertilizer $\left(T_{5}\right)$, and Farmyard manure +biofertilizer $\left(T_{6}\right)$.

Table 4. Effect of organic, inorganic, and biofertilizers on plant growth characteristics (plant dry yield, leaves dry yield, and leaf area) of Jew's mallow (Corchorus olitorius L.) plants.

\begin{tabular}{|c|c|c|c|c|c|c|c|c|c|}
\hline \multirow{2}{*}{ Treatment } & \multicolumn{2}{|c|}{ Plant Dry Weight $\left(\mathrm{g} \mathrm{m}^{-2}\right)$} & \multirow{2}{*}{ Means } & \multicolumn{2}{|c|}{ Leaves Dry Weight $\left(\mathrm{g} \mathrm{m}^{-2}\right)$} & \multirow{2}{*}{ Means } & \multicolumn{2}{|c|}{ Leaf Area $\left(\mathrm{cm}^{2} \mathrm{~m}^{-2}\right)$} & \multirow{2}{*}{ Means } \\
\hline & 2017 & 2018 & & 2017 & 2018 & & 2017 & 2018 & \\
\hline $\mathrm{T}_{1}$ & $274.92 \pm 6.02^{\mathrm{e}}$ & $138.78 \pm 6.22^{c}$ & $206.85^{\mathrm{e}}$ & $112.20 \pm 11.05^{c}$ & $95.20 \pm 13.39^{d}$ & $103.7^{\mathrm{d}}$ & $219.50 \pm 2.38^{f}$ & $199.56 \pm 10.18^{\mathrm{e}}$ & $209.53^{f}$ \\
\hline $\mathrm{T}_{2}$ & $416.96 \pm 9.12^{c}$ & $326.56 \pm 22.70^{c}$ & $317.76^{c}$ & $184.94 \pm 17.77^{b}$ & $123.84 \pm 5.03^{c}$ & $154.39^{c}$ & $321.79 \pm 1.79^{c}$ & $290.26 \pm 1.32^{c}$ & 306.025 \\
\hline $\mathrm{T}_{3}$ & $560.85 \pm 10.44^{b}$ & $398.65 \pm 10.17^{b}$ & $479.75^{b}$ & $198.14 \pm 7.05^{b}$ & $155.91 \pm 9.20^{\mathrm{b}}$ & $177.03^{b}$ & $336.65 \pm 5.93^{b}$ & $308.25 \pm 8.66^{b}$ & $322.45^{\mathrm{b}}$ \\
\hline $\mathrm{T}_{4}$ & $328.60 \pm 42.73^{d}$ & $272.47 \pm 17.12^{d}$ & $300.54^{d}$ & $167.28 \pm 29.13^{b}$ & $120.99 \pm 1.59^{c}$ & $144.14^{\mathrm{c}}$ & $247.83 \pm 4.22^{\mathrm{e}}$ & $205.36 \pm 7.48$ de & $226.59^{\mathrm{e}}$ \\
\hline $\mathrm{T}_{5}$ & $713.36 \pm 27.96^{a}$ & $580.22 \pm 23.39^{a}$ & $646.79^{a}$ & $240.42 \pm 15.81^{a}$ & $206.29 \pm 7.00^{\mathrm{a}}$ & $223.35^{\mathrm{a}}$ & $392.15 \pm 7.78^{\mathrm{a}}$ & $346.85 \pm 9.28^{\mathrm{a}}$ & $369.5^{\mathrm{a}}$ \\
\hline $\mathrm{T}_{6}$ & $311.85 \pm 26.62 \mathrm{de}$ & $256.33 \pm 10.90^{d}$ & $284.09^{d}$ & $154.20 \pm 41.25^{b}$ & $119.75 \pm 4.16^{c}$ & $136.97^{c}$ & $257.86 \pm 5.79^{d}$ & $217.15 \pm 3.91^{\mathrm{d}}$ & $237.50^{\mathrm{d}}$ \\
\hline Means & $434.42^{\mathrm{a}}$ & $286.11^{\mathrm{b}}$ & & $176.20^{\mathrm{a}}$ & $136.99^{b}$ & & $295.96^{\mathrm{a}}$ & $261.24^{\mathrm{b}}$ & \\
\hline
\end{tabular}

Values are means of three replicates; different letters in the same column indicate significant differences according to Duncan's multiple range test at $p \leq 0.05$. Where without fertilization

$\left(T_{1}\right)$, NPK fertilizer $\left(T_{2}\right)$, farmyard manure $\left(T_{3}\right)$, biofertilizer $\left(T_{4}\right)$, NPK+biofertilizer $\left(T_{5}\right)$, and Farmyard manure +biofertilizer $\left(T_{6}\right)$. 
Table 5. Effect of organic, inorganic, and biofertilizers on plant growth characteristics and chemical contents (leaves weight incidence, dry matter content, and protein) of Jew's mallow (Corchorus olitorius L.) plants.

\begin{tabular}{|c|c|c|c|c|c|c|c|c|c|}
\hline \multirow{2}{*}{ Treatment } & \multicolumn{2}{|c|}{ Leaves Weight Incidence (\%) } & \multirow{2}{*}{ Means } & \multicolumn{2}{|c|}{ Dry Matter Content \% } & \multirow{2}{*}{ Means } & \multicolumn{2}{|c|}{ Protein $(\%)$} & \multirow{2}{*}{ Means } \\
\hline & 2017 & 2018 & & 2017 & 2018 & & 2017 & 2018 & \\
\hline $\mathrm{T}_{1}$ & $40.78 \pm 3.37^{\mathrm{a}-\mathrm{c}}$ & $68.63 \pm 5.55^{\mathrm{a}}$ & $54.71^{\mathrm{a}}$ & $23.6 \pm 3.76^{b}$ & $27.27 \pm 2.90^{\mathrm{a}-\mathrm{c}}$ & $25.44^{\mathrm{d}}$ & $8.00 \pm 0.25^{f}$ & $7.27 \pm 0.28^{f}$ & $7.64^{\mathrm{f}}$ \\
\hline $\mathrm{T}_{2}$ & $44.34 \pm 3.97^{\mathrm{a}-\mathrm{c}}$ & $38 \pm 1.21^{\mathrm{cd}}$ & $41.17^{b c}$ & $28.3 \pm 1.31^{\mathrm{ab}}$ & $24.63 \pm 1.20^{c}$ & $26.47^{c}$ & $17.67 \pm 0.38^{b}$ & $16.44 \pm 0.23^{b}$ & $17.06^{\mathrm{b}}$ \\
\hline $\mathrm{T}_{3}$ & $35.35 \pm 1.91 \mathrm{bc}$ & $39.11 \pm 2.21^{b-d}$ & $37.23^{c}$ & $26.5 \pm 1.18^{a b}$ & $26.33 \pm 1.70 \mathrm{bc}$ & $26.42^{c}$ & $14.19 \pm 0.35^{\mathrm{d}}$ & $13.71 \pm 0.22^{\mathrm{d}}$ & $13.95^{\mathrm{d}}$ \\
\hline $\mathrm{T}_{4}$ & $52.02 \pm 14.35^{\mathrm{a}}$ & $44.5 \pm 2.30 \mathrm{bc}$ & $48.26^{\mathrm{ab}}$ & $31.0 \pm 5.85^{\mathrm{a}}$ & $27.97 \pm 1.01 \mathrm{ab}$ & $29.49^{\mathrm{a}}$ & $12.02 \pm 0.29 \mathrm{e}$ & $10.56 \pm 0.33^{\mathrm{e}}$ & $11.29^{\mathrm{e}}$ \\
\hline $\mathrm{T}_{5}$ & $33.68 \pm 0.89^{c}$ & $35.61 \pm 2.40^{\mathrm{d}}$ & $34.65^{c}$ & $26.8 \pm 1.24 \mathrm{ab}$ & $29.57 \pm 1.34^{\mathrm{a}}$ & $28.19^{b}$ & $19.00 \pm 0.44^{\mathrm{a}}$ & $18.31 \pm 0.29^{\text {a }}$ & $18.66^{\mathrm{a}}$ \\
\hline $\mathrm{T}_{6}$ & $48.99 \pm 9.01 \mathrm{ab}$ & $46.78 \pm 2.69 \mathrm{~b}$ & $47.89 \mathrm{ab}$ & $27.8 \pm 5.28 \mathrm{ab}$ & $27.99 \pm 0.85 \mathrm{ab}$ & $27.90^{\mathrm{b}}$ & $15.83 \pm 0.29^{c}$ & $14.69 \pm 0.25^{c}$ & $15.26^{c}$ \\
\hline Means & $42.53^{\mathrm{a}}$ & $45.44^{\mathrm{a}}$ & & $27.33^{\text {a }}$ & $27.29^{\mathrm{a}}$ & & $14.45^{\mathrm{a}}$ & $13.50^{\mathrm{b}}$ & \\
\hline
\end{tabular}

Values are means of three replicates; different letters in the same column indicate significant differences according to Duncan's multiple range test at $p \leq 0.05$. Where without fertilization

$\left(T_{1}\right)$, NPK fertilizer $\left(T_{2}\right)$, farmyard manure $\left(T_{3}\right)$, biofertilizer $\left(T_{4}\right)$, NPK+biofertilizer $\left(T_{5}\right)$, and Farmyard manure +biofertilizer $\left(T_{6}\right)$.

Table 6. Effect of organic, inorganic, and biofertilizers on compositional variables (N-Content, P-Content, and K-Content) of Jew's mallow (Corchorus olitorius L.) plants.

\begin{tabular}{|c|c|c|c|c|c|c|c|c|c|}
\hline \multirow{2}{*}{ Treatment } & \multicolumn{2}{|c|}{$\mathrm{N}$-Content in Leaves $\left(\mathrm{mg} 100 \mathrm{~g}^{-1}\right)$} & \multirow{2}{*}{ Means } & \multicolumn{2}{|c|}{ P-Content in Leaves $\left(\mathrm{mg} 100 \mathrm{~g}^{-1}\right)$} & \multirow{2}{*}{ Means } & \multicolumn{2}{|c|}{ K-Content in Leaves ( $\mathrm{mg}^{100 \mathrm{~g}^{-1}}$ ) } & \multirow{2}{*}{ Mean } \\
\hline & 2017 & 2018 & & 2017 & 2018 & & 2017 & 2018 & \\
\hline $\mathrm{T}_{1}$ & $1.28 \pm 0.04^{\mathrm{f}}$ & $1.16 \pm 0.05^{\mathrm{f}}$ & $1.22^{\mathrm{f}}$ & $0.35 \pm 0.04^{\mathrm{f}}$ & $0.31 \pm 0.04^{\mathrm{e}}$ & $0.33^{\mathrm{f}}$ & $1.15 \pm 0.05^{\mathrm{f}}$ & $1.03 \pm 0.02^{\mathrm{f}}$ & $1.09^{\mathrm{f}}$ \\
\hline $\mathrm{T}_{2}$ & $2.83 \pm 0.06^{b}$ & $2.63 \pm 0.04^{b}$ & $2.73^{\mathrm{b}}$ & $0.85 \pm 0.06^{b}$ & $0.70 \pm 0.02^{b}$ & $0.78^{\mathrm{b}}$ & $1.91 \pm 0.03^{b}$ & $1.75 \pm 0.04^{b}$ & $1.83^{b}$ \\
\hline $\mathrm{T}_{3}$ & $2.27 \pm 0.06^{\mathrm{d}}$ & $2.19 \pm 0.04$ & $2.23^{\mathrm{d}}$ & $0.57 \pm 0.02^{d}$ & $0.41 \pm 0.02^{\mathrm{d}}$ & $0.49^{\mathrm{d}}$ & $1.62 \pm 0.04^{\mathrm{d}}$ & $1.44 \pm 0.04^{\mathrm{d}}$ & $1.53^{\mathrm{d}}$ \\
\hline $\mathrm{T}_{4}$ & $1.92 \pm 0.05^{\mathrm{e}}$ & $1.69 \pm 0.05^{\mathrm{e}}$ & $1.81^{\mathrm{e}}$ & $0.45 \pm 0.03^{\mathrm{e}}$ & $0.36 \pm 0.02 \mathrm{de}$ & $0.41^{\mathrm{e}}$ & $1.41 \pm 0.03^{\mathrm{e}}$ & $1.32 \pm 0.03^{\mathrm{e}}$ & $1.37^{\mathrm{e}}$ \\
\hline $\mathrm{T}_{5}$ & $3.04 \pm 0.07^{\mathrm{a}}$ & $2.93 \pm 0.05^{\mathrm{a}}$ & $2.99^{a}$ & $0.95 \pm 0.04^{\mathrm{a}}$ & $0.81 \pm 0.05^{\mathrm{a}}$ & $0.88^{\mathrm{a}}$ & $2.09 \pm 0.05^{\mathrm{a}}$ & $1.93 \pm 0.03^{a}$ & $2.01^{\mathrm{a}}$ \\
\hline $\mathrm{T}_{6}$ & $2.53 \pm 0.05^{c}$ & $2.35 \pm 0.04^{\mathrm{c}}$ & $2.44^{\mathrm{c}}$ & $0.75 \pm 0.03^{c}$ & $0.61 \pm 0.03^{c}$ & $0.68^{\mathrm{c}}$ & $1.75 \pm 0.03^{c}$ & $1.60 \pm 0.03^{c}$ & $1.68^{c}$ \\
\hline Means & $2.31^{\mathrm{a}}$ & $2.16^{\mathrm{b}}$ & & $0.65^{\mathrm{a}}$ & $0.53^{\mathrm{b}}$ & & $1.66^{\mathrm{a}}$ & $1.60^{\mathrm{b}}$ & \\
\hline
\end{tabular}

Values are means of three replicates; different letters in the same column indicate significant differences according to Duncan's multiple range test at $p \leq 0.05$. Where without fertilization

$\left(T_{1}\right)$, NPK fertilizer $\left(T_{2}\right)$, farmyard manure $\left(T_{3}\right)$, biofertilizer $\left(T_{4}\right)$, NPK+biofertilizer $\left(T_{5}\right)$, and Farmyard manure +biofertilizer $\left(T_{6}\right)$. 
The average leaf chlorophyll content the first season was higher than in the second season in all variants, where the highest value of leaf chlorophyll content $41.21 \mathrm{mg} \mathrm{g}^{-1}$ was obtained in $\mathrm{T}_{5}$, while the lowest one $\left(29.47 \mathrm{mg} \mathrm{g}^{-1}\right.$ ) was recorded in $\mathrm{T}_{1}$ (Figure 2).

ㅁ2017 2018

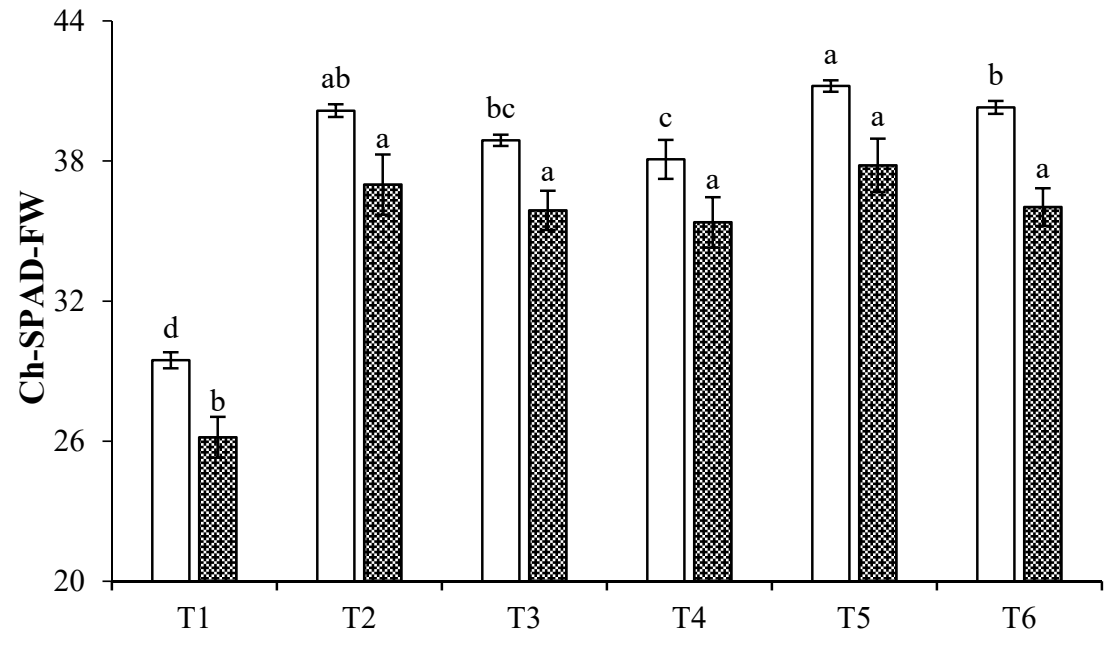

Figure 2. Effect of organic, inorganic, and biofertilizers on leaf chlorophyll content of Jew's mallow (Corchorus olitorius L.). Each column represents the mean of three replicates; different letters on similar columns indicate significant differences using Duncan's multiple range test at $p \leq 0.05$.

\subsection{Soil Properties at the End of the Experimental Period}

The result of soil properties after harvesting Jew's mallow plant showed that the soil was variably influenced by the different treatments. The average values for the soil organic-C (\%) contents were influenced by the individual treatments. The highest value for soil organic- $\mathrm{C}$, as shown in Figure $3 \mathrm{a}$, was observed in $\mathrm{T}_{3}$ in both of seasons and in $\mathrm{T}_{6}$ in the 2018 season, while the lowest values were recorded in $\mathrm{T}_{1}$ and $\mathrm{T}_{2}$. As shown in Figure $3 \mathrm{~b}$, the application of organic manure with biofertilizers significantly enhanced the CEC value. The highest average values CEC were noticed in $\mathrm{T}_{6}\left(17.98 \mathrm{cmol} \mathrm{kg}^{-1}\right)$, and $\mathrm{T}_{3}\left(17.93 \mathrm{cmol} \mathrm{kg}^{-1}\right)$ which were statistically undifferentiated. The lowest value (15.72 and $\left.16.01 \mathrm{cmol} \mathrm{kg}^{-1}\right)$ were obtained in control $\left(\mathrm{T}_{1}\right)$ and NPK fertilizer $\left(\mathrm{T}_{2}\right)$, respectively. The treatment effects on the average soil bulk density for two seasons are presented in Figure 3c. These treatments $\left(\mathrm{T}_{3}-\mathrm{T}_{6}\right)$ had positive and significant effects on soil bulk density. The bulk density was reduced in the $\mathrm{T}_{3}-\mathrm{T}_{6}$ treatments $\left(1.39 \mathrm{~g} \mathrm{~cm}^{-3}\right.$, on average) and showed statistically lower values than obtained in the control $\left(1.46 \mathrm{~g} \mathrm{~cm}^{-3}\right)$. 
a

$\square 2017 \approx 2018$
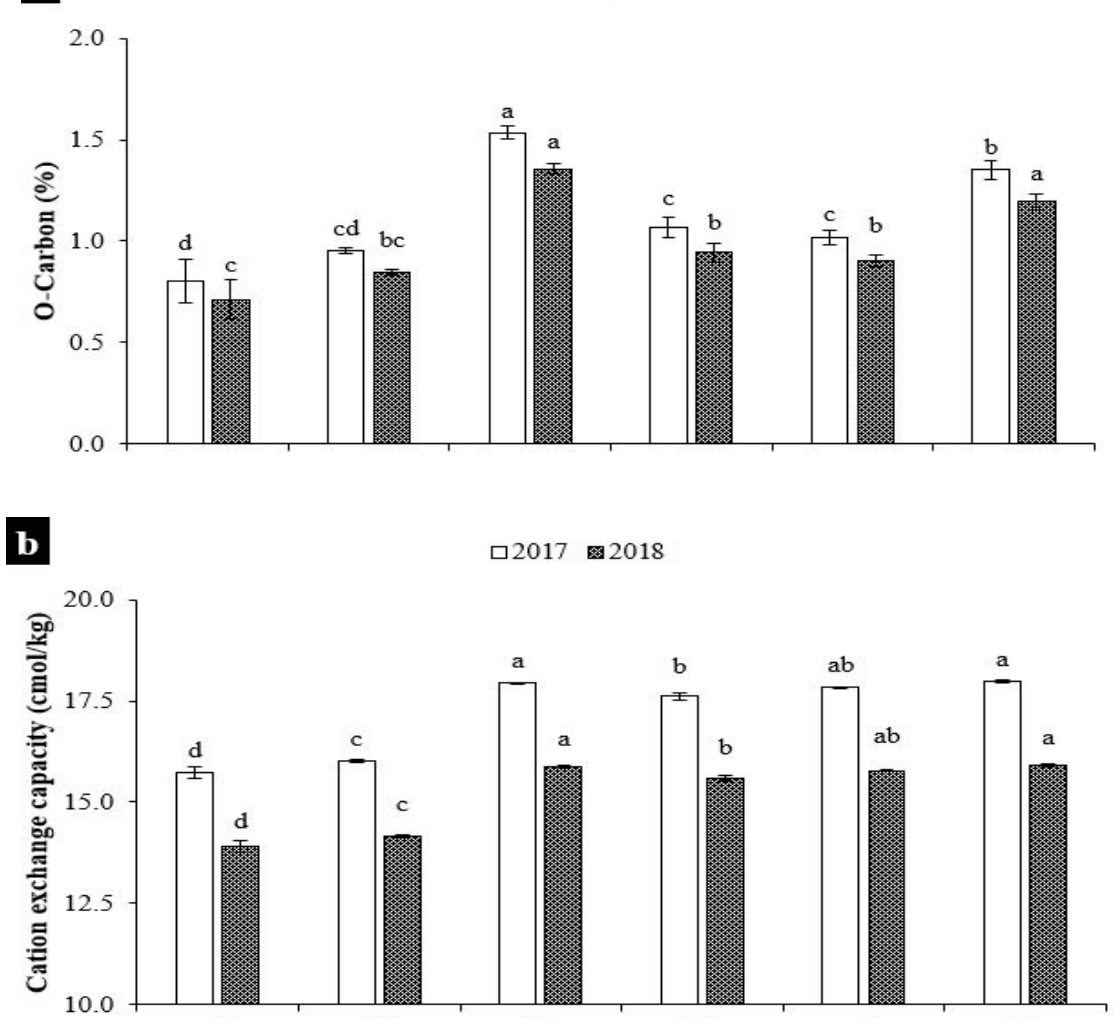

$\mathbf{c}$

$\square 2017$ ख 2018

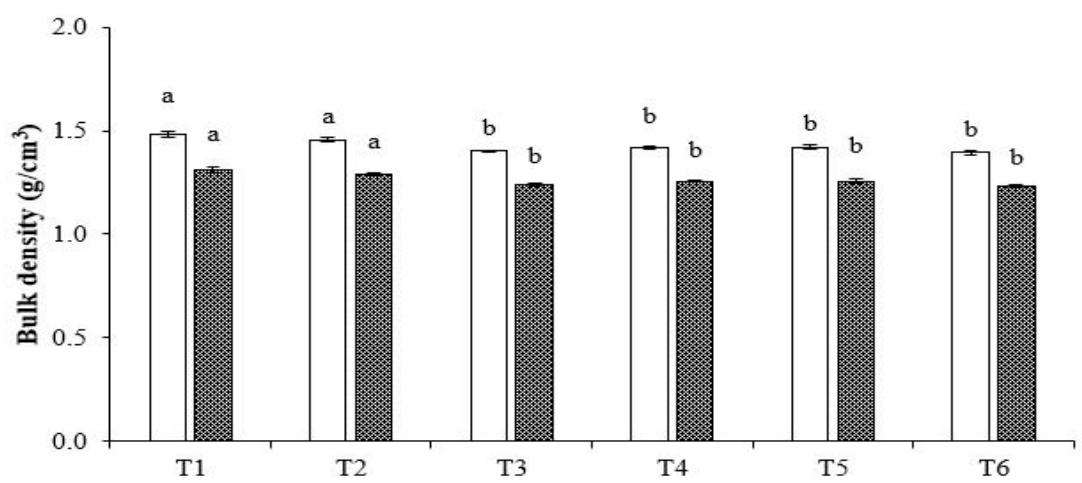

Figure 3. Effect of organic, inorganic, and biofertilizers on the soil properties [O-carbon (a), cation exchange capacity (b) and bulk density (c)] on which Jew's mallow (Corchorus olitorius L.) was grown. Each column represents the mean of three replicates; different letters on similar columns indicate significant differences using Duncan's multiple range test at $p \leq 0.05$.

\section{Discussion}

\subsection{Growth Variables}

The positive effects of NPK with biofertilizers $\left(\mathrm{T}_{5}\right)$ on growth variables may have been due to the efficiency of the microorganism in the biofertilizer in immobilizing $\mathrm{N}$ for a longer time in the form of $\mathrm{NH}_{4}{ }^{+}$, which helped in the nutrient uptake by the plant [30]. According to Alori and Babalola [31], a biofertilizer is a living organisms that is added into the soil as inoculant that helps to provide certain nutrients for crop growth. Furthermore, these positive effects may be related to the increased availability of nutrients provided by mineral fertilization, which also served as an energy source for 
the microbial community [32]. Similar to our findings, Al-Zabee and Al-Maliki [32] reported that the combination of mycorrhizal fungi, algae, and yeast with a higher rate of chemical fertilization (120 kg N, $60 \mathrm{~kg}$ P, and $200 \mathrm{~kg} \mathrm{~K}$ per hectare) was beneficial to soil microbial metabolism and potato yield. Besides, Asmamaw, et al. [33] reported that the application of dry cyanobacterial biofertilizer could serve as an auxiliary $\mathrm{N}$ source to inorganic fertilizer for pepper, maize, and kale production. It was also noted that the use of biofertilizers in combination with chemical $\mathrm{N}$ fertilizers increased growth, productivity, and chemical compositions of the dill plant (Anethum graveolens L.) compared to the untreated control, where the highest values of plant growth were recorded when biofertilizer was used in combination to $97.6 \mathrm{~kg} \cdot \mathrm{ha}^{-1} \mathrm{~N}$ [34]. Observations have also shown that the most effective treatment for growth characteristics of barley cultivars (Giza-128 and Giza-129) under newly reclaimed sandy soil was $178.57 \mathrm{~kg} \mathrm{~N} \mathrm{ha}^{-1}+$ Yeast [35]. Moreover, Sen, et al. [36] reported that the combined use

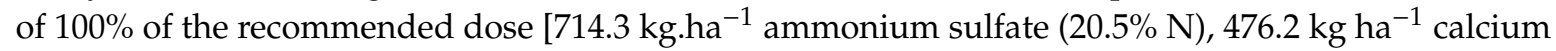
superphosphate $\left(15.5 \% \mathrm{P}_{2} \mathrm{O}_{5}\right)$, and $119.05 \mathrm{~kg} \mathrm{ha}^{-1}$ potassium sulfate $\left.\left(48 \% \mathrm{k}_{2} \mathrm{O}\right)\right]$ of inorganic fertilizers with biofertilizer was optimal for increasing oil yield $\left(33.22 \mathrm{mg} \mathrm{g}^{-1}\right)$ of cumin black (Nigella sativa L.). The co-application of biofertilizers like Azospirillum and Phosphobacteria spp. and inorganic fertilizers had a significant effect on the growth variables of cucumber (Cucumis sativus L.) [37]. Application of biofertilizer at $300-400 \mathrm{~kg} \mathrm{ha}^{-1}$ dose combined with inorganic fertilizer at $75 \%$ of crop requirement dose was the best combination for increasing NPK nutrient uptake for rice crop and weight of milled dry rice. Marlina, et al. [38] recommended the use of dry cyanobacterial biofertilizer which serve as a supplementary $\mathrm{N}$ source in place of inorganic fertilizer for rice production in inception soil of lowland swamp area.

\subsection{Compositional Variables}

The data in Tables 5 and 6 indicated differences in the average proportion of protein, N, P, and $\mathrm{K}$ content in leaves among treatments. The NPK with biofertilizers $\left(T_{5}\right)$ treatment significantly increased these variables in both seasons. The results presented by Hellal, Mahfouz and Hassan [34] showed that the highest NPK-accumulation were recorded after the combination of biofertilizer with $476.2 \mathrm{~kg} \mathrm{ha}^{-1}$ ammonium sulphate $(20.5 \% \mathrm{~N})$ in the Dill plant. The pronounced positive effect on protein, $\mathrm{N}, \mathrm{P}$, and K in leaves resulting from $\mathrm{T}_{5}$ addition may be attributed to the increased uptake of $\mathrm{N}$ by plants, and thus, the biosynthesis of protein was increased. Moreover, Tisdale et al. [39] reported that the addition of $\mathrm{N}$ in combination with adequate $\mathrm{P}$ tended to increase K-uptake by plants. They also showed that $\mathrm{K}$ concentration may be high in the $\mathrm{NH}_{4}{ }^{+}$-nourished plants as it is adsorbed by soil colloids, so it does not get leached from the soil. This gave the plant a greater chance of taking up N, and thus some nutrients, to build the dry matter. Also, data in Figure 2 for leaf chlorophyll content supported the results of Hellal, Mahfouz and Hassan [34], where it was observed that the highest values of chlorophyll content were recorded where biofertilizer was used in combination to $97.6 \mathrm{~kg} \mathrm{ha}^{-1} \mathrm{~N}$ in the dill plant. Moreover, Sen, Choudhuri, Chatterjee and Jana [36] reported that the combination of $100 \%$ of the recommended dose of inorganic fertilizers with biofertilizer increased the leaf chlorophyll content $\left(13.18 \mathrm{mg} . \mathrm{g}^{-1}\right)$ in cumin black (Nigella sativa L.) in the eastern Himalayan region of West Bengal. Moreover, Youssef, et al. [40] reported that the combined application of organic manures and biofertilizer (EM) had a synergistic effect on the total chlorophyll content of plants.

\subsection{Soil Properties at the End of the Experimental Period}

The combined application of the biofertilizer with the organic or the inorganic fertilizer was beneficial for the physical and chemical properties of soil and were important for the quality and productivity of the soil. The application of organic fertilizer in $\mathrm{T}_{3}$ and its combination with biofertilizer in $\mathrm{T}_{6}$ increased the soil organic-C content of the soil at the end of experimental period by $91.25 \%$ and $68.75 \%$, respectively, over the control treatment (without fertilization $\mathrm{T}_{1}$ ). This organic fertilizer in the soil can increase the soil organic- $\mathrm{C}$ due to higher soil organic matter added from organic fertilizer. This serves as nutrient sources for plants and improves physical, chemical, and biological properties 
of the soil through improved structure and stable aggregates. This is because organic matrices are a natural chelating material with high moisture retention capacity $[41,42]$. These results are in agreement with Nesgea, et al. [43], who reported that the application of organic fertilizer increased the soil organic-C content after harvest by up to $65 \%$.

As for the cation exchange capacity of the soil, our results showed that the application of organic fertilizer with biofertilizer increased in CEC of the soil after crop harvest, which were statistically undifferentiated with $T_{3}$ and $T_{5}$. The increased CEC might be attributed to the addition of organic fertilizer with the biofertilizer, which might have helped in releasing more nutrients into the soil. This could be an indication of increased exchange sites on the surface of the soil colloids. In line with this result, Tana and Woldesenbet [44] reported that CEC significantly increased with increasing organic fertilizer $\left(15\right.$ ton $\mathrm{ha}^{-1}$ ) with inorganic fertilizer.

The data in Figure $3 c$ indicated that there were no differences between treatments $\left(T_{3}, T_{4}, T_{5}\right.$, and $\mathrm{T}_{6}$ ), but the highest average reduction in soil bulk density was recorded in farmyard manure +biofertilizer $\left(\mathrm{T}_{6}\right)$. Soil bulk density was reduced after the combined use of organic manure with biofertilizer $\left(\mathrm{T}_{6}\right)$ compared to soil amended with only inorganic fertilizer $\left(\mathrm{T}_{3}\right)$. This could be due to improved soil aggregation as a result of decreased soil bulk density. Several studies have shown that the appropriate addition of combined biofertilizers, inorganic and organic, improved soil porosity and decreased its bulk density. Our results are in harmony with Khan, et al. [45] who reported that organic fertilizer improved soil organic matter content and decreased soil bulk density.

\section{Conclusions}

Biofertilizers play a significant role in improving soil structure, and inorganic fertilizers are important due to their ability to provide essential nutrients, resulting in the better growth and productivity of crops. The results of the present study, conducted on a silty loam soil and in semi-arid climate conditions, revealed that the Jew's mallow plants treated with the combined application of biofertilizer and NPK fertilizer showed maximum growth and productivity among all other treatments. Although the current study unfolded the performance ability of a neglected crop under the application of different kinds of fertilizers, there is a further need to understand the molecular mechanism behind it and to improve the fertilization techniques and material according to the need for crops.

Author Contributions: M.A.Y. and A.F.Y. equally contributed in experimentation and draft preparation; M.M.A. and M.M.I. helped in data analysis and editing; Y.X. reviewed and editing; R.P.M. helped in draft preparation and revised the manuscript. All authors have read and agreed to the published version of the manuscript.

Funding: This research received no external funding.

Acknowledgments: Thanks to all field technicians at College of Agriculture, Al-Azhar University branch Assiut, Egypt and College of Horticulture, Fujian Agriculture and Forestry University, Fuzhou, China.

Conflicts of Interest: The authors declare no conflict of interest.

\section{References}

1. Ierna, A.; Mauro, R.P.; Mauromicale, G. Improved yield and nutrient efficiency in two globe artichoke genotypes by balancing nitrogen and phosphorus supply. Agron. Sustain. Dev. 2012, 32, 773-780. [CrossRef]

2. Kumar, P.; Pandey, S.; Singh, B.; Singh, S.; Kumar, D. Influence of source and time of potassium application on potato growth, yield, economics and crisp quality. Potato Res. 2007, 50, 1-13. [CrossRef]

3. Adeniyan, O.; Ojeniyi, S. Effect of poultry manure, NPK 15-15-15 and combination of their reduced levels on maize growth and soil chemical properties. Niger. J. Soil Sci. 2005, 15, 34-41.

4. Bot, A.; Benites, J. The Importance of Soil Organic Matter: Key to Drought-Resistant Soil and Sustained Food Production; Food and Agriculture Organization of the United Nations: Rome, Italy, 2005.

5. Baghdadi, A.; Halim, R.A.; Ghasemzadeh, A.; Ramlan, M.F.; Sakimin, S.Z. Impact of organic and inorganic fertilizers on the yield and quality of silage corn intercropped with soybean. PeerJ 2018, 6, e5280. [CrossRef] [PubMed] 
6. Adebayo, O.; Akoun, J. Effect of organic manure and spacing on the yield and yield components of Amaranthus cruentus. In Proceedings of the 20th Annual Conference of Horticultural Society of Nigeria Held at National Horticultural Research Institute (NIHORT) Auditorium Ibadan, Ibadan, Nigeria, 14-17 May 2002; pp. 30-32.

7. Cocking, E.C. Helping plants get more nitrogen from the air. Eur. Rev. 2000, 8, 193-200. [CrossRef]

8. Shariati, S.; Alikhani, H.A.; Pourbabaei, A. Application of vermicompost as a carrier of phosphate solubilizing bacteria (Pseudomonas fluorescens) in increase growth parameters of maize. Int. J. Agron. Plant Prod. 2013, 4, 2010-2017.

9. Bargaz, A.; Lyamlouli, K.; Chtouki, M.; Zeroual, Y.; Dhiba, D. Soil microbial resources for improving fertilizers efficiency in an integrated plant nutrient management system. Front. Microbiol. 2018, 9, 1606. [CrossRef]

10. Mazher, A.; Abdel-Aziz, N.; El-Dabh, R.; El-Khateeb, M.; Abd El-Badaie, A. Effect of bio fertilization on growth and constituents of Moringa oleifera Lam. Plants. Middle East J. Agric. Res. 2014, 3, 793-798.

11. Rajasekaran, S.; Sundaramoorthy, P. Effect of FYM, N, P fertilizers and biofertilizers on germination and growth of paddy (Oryza sativa L). Int. Lett. Nat. Sci. 2015, 8, 59-65.

12. Youssef, M.A. Impact of bio-fertilizers on growth and yield of Moringa oleifera Lam. Plants Al-Azhar. J. Agric. Res. 2016, 26, 127-138.

13. Grubben, G.L.H.; Denton, O.A. Plant Resources of Tropical Africa 2. Vegetables; PROTA Foundation: Wageningen, The Netherlands, 2004.

14. Odofin, A.; Oladiran, J.; Oladipo, J.; Wuya, E. Determination of evapotranspiration and crop coefficients for bush okra (Corchorus olitorius) in a sub-humid area of Nigeria. Afr. J. Agric. Res. 2011, 6, 3949-3953.

15. Nwangburuka, C.; Olawuyi, O.; Oyekale, K.; Ogunwenmo, K.; Denton, O.; Nwankwo, E. Growth and yield response of Corchorus olitorius in the treatment of Arbuscular mycorrhizae (AM), Poultry manure (PM), Combination of AM-PM and Inorganic Fertilizer (NPK). Adv. Appl. Sci. Res. 2012, 3, 1466-1471.

16. Youssef, A.F.; Younes, N.A.; Youssef, M. Genetic diversity in Corchorus olitorius L. revealed by morphophysiological and molecular analyses. Mol. Biol. Rep. 2019, 46, 2933-2940. [PubMed]

17. Mabhaudhi, T.; Chimonyo, V.G.; Chibarabada, T.P.; Modi, A.T. Developing a roadmap for improving neglected and underutilized crops: A case study of South Africa. Front. Plant Sci. 2017, 8, 2143. [PubMed]

18. Ghoneim, I.; El-Araby, S. Effect of organic manure source and biofertilizer type on growth, productivity and chemical composition of Jew's Mallow (Corchorus Olitorious L.) plants. J Agric. Env. Sci. Alex. Univ. Egypt 2003, 2, 88-105.

19. Isuosuo, C.; Akaneme, F.; Abu, N. Nutritional evaluation of the seeds of Corchorus olitorius: A neglected and underutilized species in Nigeria. Pak. J. Nutr. 2019, 18, 692-703.

20. Ogunrinde, A.; Fasinmirin, J. Soil moisture distribution pattern and yield of jute mallow (Corchorus olitorius) under three different soil fertility management. COLERM Proc. 2012, 2, 372-380.

21. Olaniyi, J.; Ajibola, A. Growth and yield performance of Corchorus olitorius varieties as affected by nitrogen and phosphorus fertilizers application. Am.-Eurasian J. Sustain. Agric. 2008, 2, 234-241.

22. Aisha, H.A.; Hafez, M.M.; Asmaa, R.M.; Shafeek, M. Effect of Bio and chemical fertilizers on growth, yield and chemical properties of spinach plant (Spinacia oleracea L.). Middle East J. Agric. Res. 2013, 2, 16-20.

23. Page, A.L.; Miller, R.H.; Keeney, D.R. Methods of Soil Analysis; American Society of Agronomy: Madison, WI, USA, 1982.

24. Silva, F.C.D. Manual de Análises Químicas de Solos, Plantas e Fertilizantes; Embrapa Informação Tecnológica: Rio de Janeiro, Brazil, 2009.

25. Hassan, A.A. Post Harvest Technology and Physiology of Fruit Vegetables (In Arabic); Al-Dar Al-Arabiah Lil Nashr Wa Al-Tawsia: Cairo, Egypt, 2011.

26. Pandey, S.; Singh, H. A simple, cost-effective method for leaf area estimation. J. Bot. 2011, 2011, 1-6.

27. Clark, M.S.; Horwath, W.R.; Shennan, C.; Scow, K.M. Changes in soil chemical properties resulting from organic and low-input farming practices. Agron. J. 1998, 90, 662-671. [CrossRef]

28. Motsara, M.; Roy, R.N. Guide to Laboratory Establishment for Plant Nutrient Analysis; Food and Agriculture Organization of the United Nations Rome: Rome, Italy, 2008.

29. Duncan, D.B. Multiple range and multiple F tests. J Biom. 1955, 11, 1-42. [CrossRef]

30. Di, H.; Cameron, K.J.S.U. Effects of the nitrification inhibitor dicyandiamide on potassium, magnesium and calcium leaching in grazed grassland. Soil Use Manag. 2004, 20, 2-7. [CrossRef] 
31. Alori, E.T.; Babalola, O.O. Microbial inoculants for improving crop quality and human health in Africa. Front. Microbiol. 2018, 9, 2213. [CrossRef] [PubMed]

32. Al-Zabee, M.R.; Al-Maliki, S.M. Effect of biofertilizers and chemical fertilizers on soil biological properties and potato yield. Euphrates J. Agric. Sci. 2019, 11, 1-13.

33. Asmamaw, M.; Wolde, G.; Yohannes, M.; Yigrem, S.; Woldemeskel, E.; Chala, A.; Davis, J.G. Comparison of cyanobacterial bio-fertilizer with urea on three crops and two soils of Ethiopia. Afr. J. Agric. Res. 2019, 14, 588-596.

34. Hellal, F.; Mahfouz, S.; Hassan, F. Partial substitution of mineral nitrogen fertilizer by bio-fertilizer on (Anethum graveolens L.) plant. Agri. Biol. J. N. Am. 2011, 4, 652-660.

35. Ahmed, A.G.; Hassanein, M.; Zaki, N.M. Performance of two barley cultivars as affected by nitrogen and bio-fertilizer under newly reclaimed lands. Middle East J. 2019, 8, 684-691.

36. Sen, A.; Choudhuri, P.; Chatterjee, R.; Jana, J. Influence of inorganic nutrient, organic nutrient and bio-fertilizer on growth, yield and quality of cumin black (Nigella sativa L.) in eastern Himalayan region of West Bengal. J. Pharmacogn. Phytochem. 2018, 7, 2571-2575.

37. Kumar, M.; Kathayat, K.; Singh, S.K.; Singh, L.; Singh, T. Influence of bio-fertilizers application on growth, yield and quality attributes of cucumber (Cucumis sativus L.): A review. Plant Arch. 2018, 18, 2329-2334.

38. Marlina, N.; Gofar, N.; Subakti, A.H.P.K.; Rohim, A.M. Improvement of rice growth and productivity through balance application of inorganic fertilizer and biofertilizer in inceptisol soil of lowland swamp area. AGRIVITA J. Agric. Sci. 2014, 36, 48-56. [CrossRef]

39. Tisdale, S.L.; Nelson, W.L.; Beaton, J.D. Soil Fertility and Fertilizers; Collier Macmillan Publishers: London, UK, 1985.

40. Youssef, M.A.; Elgharably, G.A.; Mahmoud, S.M.; Hegab, S. Impact of combined organic manures, Chemical fertilizer and Effective Microorganisms on growth and yield of Marjoram plants under drip and flood irrigation systems. Assiut J. Agric. Sec. 2010, 41, 91-105.

41. Bhattacharya, C.B.; Sen, S.; Korschun, D. Using corporate social responsibility to win the war for talent. MIT Sloan Manag. Rev. 2010, 49, 37-44.

42. Fageria, N.; Filho, M.B.; Moreira, A.; Guimarães, C. Foliar fertilization of crop plants. J. Plant Nutr. 2009, 32, 1044-1064. [CrossRef]

43. Nesgea, S.; Gebrekidan, H.; Sharma, J.; Berhe, T. Effects of nitrogen and phosphorus fertilizer application on yield attributes, grain yield and quality of rain fed rice (NERICA-3) in Gambella, Southwestern Ethiopia. East Afr. J. Sci. 2012, 6, 91-104.

44. Tana, T.; Woldesenbet, M. Effect of combined application of organic and mineral nitrogen and phosphorus fertilizer on soil physico-chemical properties and grain yield of food barley (Hordeum vulgare L.) in Kaffa Zone, South-western Ethiopia. Momona Ethiopian J. Sci. 2017, 9, 242-261. [CrossRef]

45. Khan, N.I.; Malik, A.U.; Umer, F.; Bodla, M.I. Effect of tillage and farm yard manure on physical properties of soil. Int. Res. J. Plant Sci. 2010, 1, 75-82.

Publisher's Note: MDPI stays neutral with regard to jurisdictional claims in published maps and institutional affiliations.

(C) 2020 by the authors. Licensee MDPI, Basel, Switzerland. This article is an open access article distributed under the terms and conditions of the Creative Commons Attribution (CC BY) license (http://creativecommons.org/licenses/by/4.0/). 